Presencia ocasional de lobo marino de

California (Zalophus californianus) en Isla

Roca Partida, Archipiélago de Revillagigedo, México

\title{
Occasional presence of a California sea lion (Zalophus californianus) at Isla Roca Partida, Revillagigedo Archipelago, México
}

Edgar Mauricio Hoyos-Padilla ${ }^{1}$ and Juan Pablo Gallo-Reynoso ${ }^{2 *}$

\begin{abstract}
'Pelagios-Kakunjá A. C. Sinaloa 1540. Las Garzas, 23070. La Paz, Baja California Sur, México. E-mail: amuakua@gmail.com (MH). ${ }^{2}$ Centro de Investigación en Alimentación y Desarrollo A. C., Unidad Guaymas. Carretera a Varadero Nacional km 6.6. Las Playitas 85480, Guaymas, Sonora, México. E-mail: jpgallo@ciad.mx (JPG).

${ }^{*}$ Corresponding author
\end{abstract}

\begin{abstract}
Introduction: California sea lions (Zalophus californianus) are a wide ranging species in the Northeastern coast of the United States and Mexico; the former limits of the species southern distribution were the Islas Marias Archipelago. Since the 1980's several individuals have been sighted outside of their range, as far north as Alaska in the U. S. A., and as far south as Chiapas in Mexico. Individuals of the species move between islands in their reproductive colonies; there are multiple records of individuals of several age classes outside of their southern limit, including a neonate in Manzanillo, Colima.
\end{abstract}

Results: We report the first record of a subadult male in the waters of Roca Partida ( $18^{\circ} 59^{\prime} 41^{\prime \prime} \mathrm{N},-112^{\circ} 04^{\prime} 07^{\prime \prime}$ W), Revillagigedo Archipelago on November 29, 2014. The individual stayed for three weeks in the area.

Discussion and conclusions: The observation took place in El Niño type conditions, in which Pacific surface water temperature increased from 1 to $1.5^{\circ} \mathrm{C}$ above normal. This event may have caused this individual sea lion to move far away from the continental coast in search for prey. This sea lion showed a good body condition. Roca Partida, is more than $650 \mathrm{~km}$ southwest of a former colony of sea lions on Islas Marías, and $600 \mathrm{~km}$ from the nearest reproductive colony at Isla Santa Margarita, Baja California Sur, this record shows the far away and occasional ranging of California sea lions outside their coastal - continental distribution.

Key words: California sea lion, distribution, Isla Roca Partida, Revillagigedo Archipelago, Zalophus californianus.

\section{Introduction}

The California sea lion is a wide ranging species, found from western Alaska at St. Paul Island (Maniscalco et al. 2004), at Vancouver Island in Canada (Bigg 1988), to the northeastern Mexican Pacific and the Gulf of California including the Tres Marias Archipelago (Allen 1880; King 1983). In its range the species inhabits islands close to areas of high primary productivity. In Mexico, they inhabit the islands of the northeastern coast of Baja California Peninsula (i. e. Coronado Islands, Guadalupe, Cedros, San Benito Archipelago, Natividad, Margarita and smaller islands), and in islands of the Gulf of California such as Consag, Lobos, San Jorge, Granito, Angel de La Guarda including Los Machos and Los Cantiles rookeries, El Rasito, Partida, San Esteban, San Pedro Mártir, San Pedro Nolasco, Farallón de San Ignacio and Los Islotes. In all these islands, California sea lions have reproductive colonies (Le Boeuf et al. 1983), but they also occupy other areas and islands near feeding grounds. 
These islands are referred to as resting rookeries; there are several of these sites on the coast of Sonora and Sinaloa, such as Puerto Libertad, in Isla Lobos, which is a large sandy island and San Ignacio, a large beach, south of Topolobampo; the last rookery is located on a small islet near Mazatlán, and constitutes the southernmost distribution of California sea lions, even though their former distribution included the Islas Marías Archipelago (Dampier 1703, in Allen 1880) in the southern Gulf of California.

Several reports state that California sea lions wander far away from their geographical distribution. Some individuals have been observed in the southern coast of Mexico, including sightings made by fishermen at Manzanillo Bay $\left(21^{\circ} 30^{\prime} \mathrm{N},-106^{\circ} 20^{\prime} \mathrm{W}\right.$; Gallo-Reynoso and Ortega 1986), a subadult male at Manzanillo thermo-electrical plant (Lechuga and Gallo-Reynoso, April 2004, unpublished data), and the presence of a neonate in the same region (Ortega-Ortiz et al. 2013), which supports that adult females of this species occasionally wander for long distances, Young et al. (2007) reported a female traveling $>600 \mathrm{~km}$ with its pup from one reproductive colony to another in the Gulf of California. At Acapulco, a subadult male was sighted at La Roqueta Island $\left(16^{\circ} 49^{\prime} \mathrm{N},-99^{\circ} 56^{\prime} \mathrm{W}\right)$ in January 22,1983 ; this event was associated to the effect of unusual cold waters $\left(18^{\circ} \mathrm{C}\right)$ in the area (Gallo-Reynoso and Ortega 1986). Two additional subadult males were observed and photographed at Acapulco port and described by the local press, one in April 26, 2004 (El Imparcial 2004), and the other in June 11, 2012 (RTG Noticias 2012).

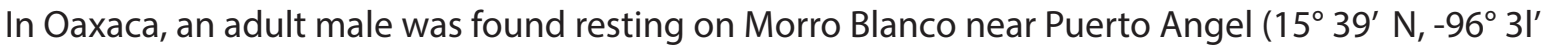
W), along the coast of Oaxaca (Mexico) on January 23, 1989 (Gallo-Reynoso and Solorzano 1991). This individual showed a good body condition, with a standard length of $2.1 \mathrm{~m}$. This sighting took place at $400 \mathrm{~km}$ south of the previous southernmost report in Acapulco by Gallo-Reynoso and Ortega (1986). Another subadult male was found at Bahía el Rascalillo, Oaxaca in March 2001 (Meraz and Sánchez-Díaz 2008). In Chiapas an adult male was found entangled in a shark gill net in February 1988, 40 - 50 km west of Puerto Madero ( $\left.14^{\circ} 42^{\prime} \mathrm{N},-92^{\circ} 47^{\prime} \mathrm{W}\right)$, near the MexicoGuatemala border (Gallo-Reynoso and Solorzano 1991), $800 \mathrm{~km}$ south of the previous report in Acapulco by Gallo-Reynoso and Ortega (1986).

These records together with additional reports confirm the extensive dispersal ability of California sea lions, even in young individuals. A two-year-old male sea lion tagged at Los Islotes $\left(24^{\circ} 35^{\prime} \mathrm{N},-110^{\circ} 23^{\prime} \mathrm{W}\right.$ ) in August 1984 (Gallo-Reynoso and Ortega 1986), swam approximately $440 \mathrm{~km}$ to San Pedro Mártir Island $\left(28^{\circ} 22^{\prime} \mathrm{N},-112^{\circ} 44^{\prime} \mathrm{W}\right)$ in the central Gulf of California where it was photographed by the senior author at in August 1985. Lowry (1985) reported that a California juvenile sea lion tagged on Santa Barbara Island, California (1983) was found dead on the coast of central Oregon in March 1984, a movement of approximately 1,700 km. There are two records of sea lions moving far to the south, a sea lion tagged on San Clemente Island, California, and resighted in Ojo de Liebre, Baja California, a distance of 620 km (Gallo-Reynoso and Ortega 1986); and a hot-branded adult male from Columbia River, Oregon, this was sighted on the San Benito Archipelago, Baja California, during the 2014 breeding season. It was a displacement south of around 2,000 km (Elorriaga-Verplancken et al. 2014). Other sea lions such as three Galápagos sea lions (Z. wollebaeki) have also been found in the coasts of Chiapas, two dead males and one four year old female in critical condition that later died of starvation. The female was found at the

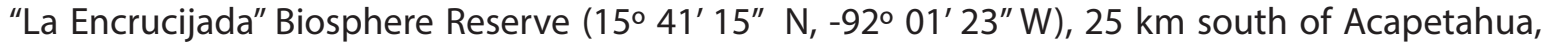
Chiapas. This location is approximately $1,800 \mathrm{~km}$ northeast of the Galapagos Islands (Ceballos et al. 2010).

We report the first record of a subadult male California sea lion that was observed by one of us (MH) on November 29, 2014 at 0955 in the waters of Roca Partida ( $18^{\circ} 59^{\prime} 41^{\prime \prime} \mathrm{N},-112^{\circ} 04^{\prime} 07^{\prime \prime}$ W) at Revillagigedo archipelago (Figure 1). The animal was found underwater and remained for three weeks around the island, trying to climb the rock, unsuccessfully. Roca Partida is an 
elevated peak of volcanic origin that reaches out from the ocean floor at 3,400 $\mathrm{m}$ as part of an unnamed submarine mountain with a summit of 1,554 $\mathrm{m}$. The island drops straight to almost 80 $\mathrm{m}$, and then gradually descends to the submarine mountain as a volcanic cone. The above water structures are composed of two lava peaks that reach $33 \mathrm{~m}$ (Richards 1964). Roca Partida is found at 153 nautical miles $(284 \mathrm{~km}$ ) east of Isla Clarión and is situated in the Clarión Fracture Zone (Richards 1964).

\section{ROCA PARTIDA}
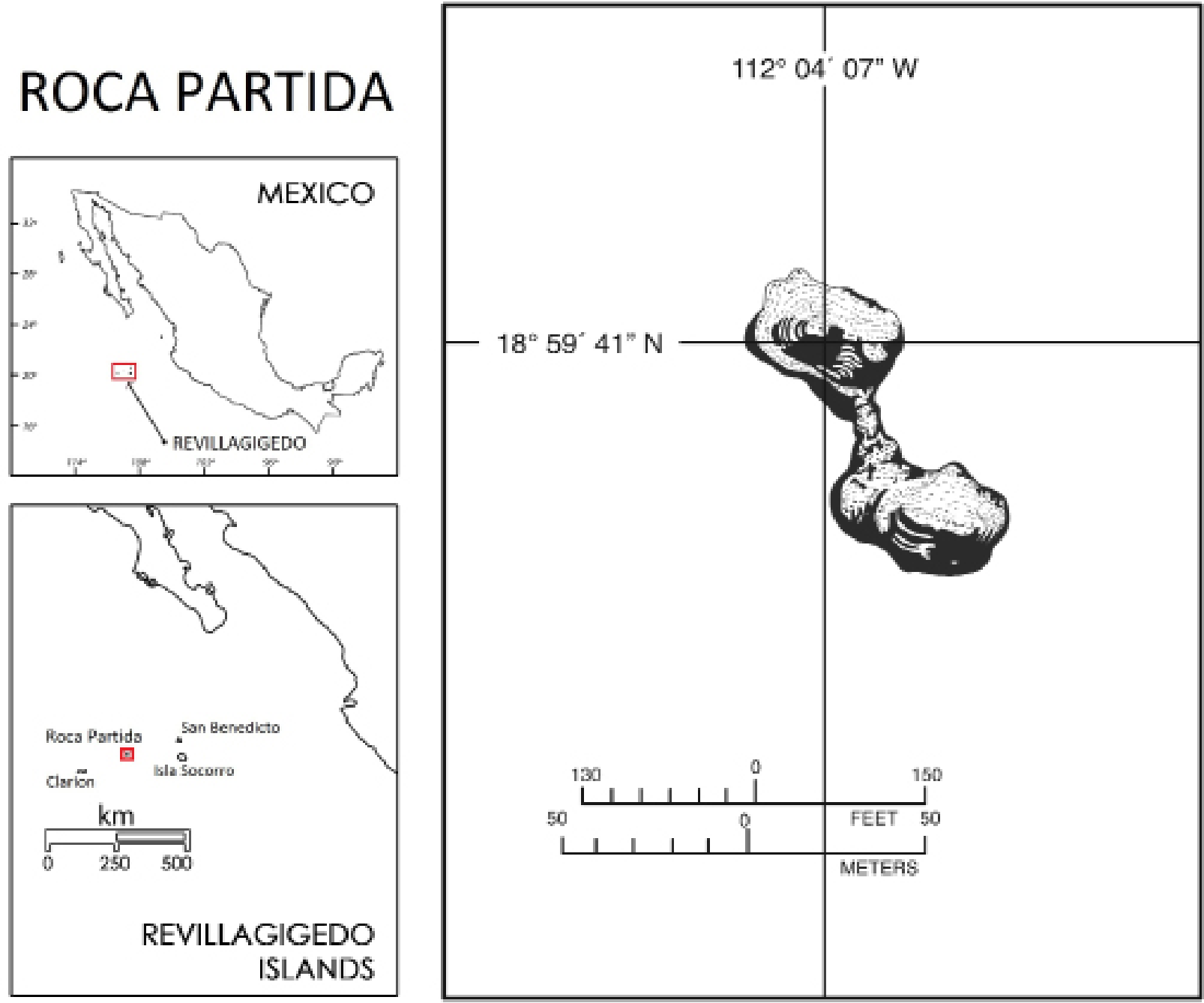

Figure 1. Roca Partida Island at Revillagigedo Archipelago, México (from Richards 1964).

Given that the observation took place in El Niño type conditions, in which Pacific surface water temperature increased from 1.0 to $1.5^{\circ} \mathrm{C}$ above normal. This event may have caused this individual sea lion to move far away from the continental coast in search for prey. El Niño events tend to diminish the overall primary production in the subtropical and temperate waters making ecosystems present a high scarcity of prey species for sea lions (Trillmich and Dellinger 1991), causing individuals of this species to disperse far from their former range (Wise et al. 2006).

The observed male was filmed, and from this video we obtained the still images to identify the sea lions as a subadult male (Figure 2); where the sagittal crest was not completely developed and the size of the individual correspond to that category. It is important to mention that this sea lion showed a good body condition. Roca Partida, where the sea lion was observed, is more than $650 \mathrm{~km}$ southwest of a locality of a colony of sea lions reported by Dampier (1703) and quoted in Allen (1880) on Islas Marías ( $\left.21^{\circ} 30^{\prime} \mathrm{N},-106^{\circ} 20^{\prime} \mathrm{W}\right) ; 810 \mathrm{~km}$ west from an earlier report of the 


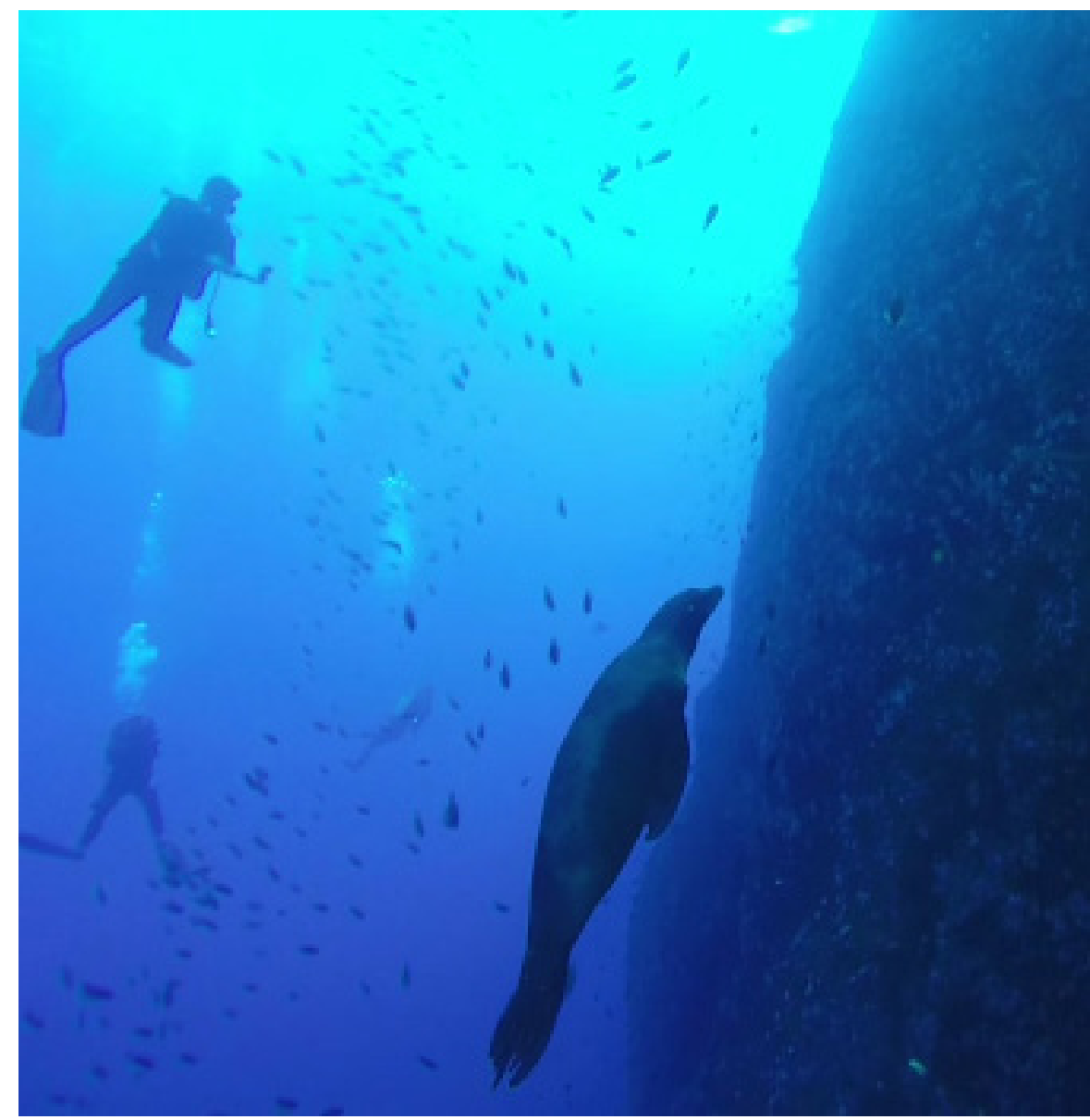

Figure 2. Subadult male California sea lion (Zalophus californianus) at Roca Partida (Film credit MH).

species at Manzanillo Bay, Colima (19 $04^{\prime} \mathrm{N},-104^{\circ} 22^{\prime} \mathrm{W}$ ) in recent years (Gallo-Reynoso and Ortega 1986; Ortega-Ortiz et al. 2013); and $600 \mathrm{~km}$ from the nearest reproductive colony at Isla Santa Margarita, Baja California Sur. The observation of several fish species, filmed in the waters of Roca Partida might explain the permanence of the sea lion in the area. At least one species of known prey was observed in large schools; the Bigeye trevally (Caranx sexfasciatus) which is preyed by sea lions at Isla Farallón de San Ignacio, Sinaloa (Pérez-Cossío 2015) but there were no evidence of foraging. It is somewhat odd to find a California sea lion at Roca Partida, when Revillagigedo Islands were home to Guadalupe fur seals (Arctocephalus townsendi; Repenning et al. 1971).

These observations suggest the continual dispersal of adult and subadult male California sea lions from the stable populations from northern latitudes. Future monitoring of these occurrences are important (Gallo-Reynoso and Ortega 1986); we add this record as an occasional extended range of Zalophus and as an alternative habitat for the species at Islas Revillagigedo, Mexico.

\section{Acknowledgments}

We thank A. Miller for the thorough review of the English and suggestions to improve the manuscript. Field work was greatly facilitated through courtesies extended to us by personnel of Club Cantamar, M/V Southern Sport, thank you. We thank two anonymous reviewers that helped us to improve this work. 


\section{Resumen}

Introducción: El lobo marino de California (Zalophus californianus) es una especie con un amplio rango de distribución en la costa nororiental de los Estados Unidos y México, siendo el límite histórico de la especie hasta el Archipiélago de las Islas Marías. A partir de los 1980s se han observado varios individuos fuera de este rango, tan al norte como Alaska y tan al sur como Chiapas en México. Los individuos de esta especie se desplazan entre las islas en sus colonias reproductivas, con movimientos muy lejanos; hay muchos registros de individuos de diferentes clases de edad fuera de su límite sur, incluyendo un neonato en Manzanillo, Colima.

Resultados: Reportamos el primer registro de un macho subadulto de lobo marino de California en las aguas de Isla Roca Partida ( $\left.18^{\circ} 59^{\prime} 41^{\prime \prime} \mathrm{N},-112^{\circ} 04^{\prime} 07^{\prime \prime} \mathrm{W}\right)$ en el Archipiélago de Revillagigedo, el 29 de Noviembre de 2014 . El individuo permaneció por tres semanas en el área.

Discusión y conclusiones: Esta observación sucedió en condiciones de El Niño, durante el cual la superficie del mar incrementa su temperatura de 1 a $1.5^{\circ} \mathrm{C}$ arriba de lo normal. Probablemente este evento causó que el individuo se alejara de la costa continental en búsqueda de alimento. Este lobo marino aparentaba una buena condición corporal. Isla Roca Partida se encuentra a más de $650 \mathrm{~km}$ al suroeste de la colonia histórica de las Islas Marías, y a $600 \mathrm{~km}$ de la colonia reproductiva más cercana en Isla Santa Margarita, Baja California Sur. Este registro muestra los largos y ocasionales desplazamientos fuera de su distribución costera - continental.

Palabras clave. Archipiélago de Revillagigedo, distribución, Isla Roca Partida, lobo marino de California, Zalophus californianus.

\section{References}

Allen, J. A. 1880. North American Pinnipeds. U. S. Geological and Geographic Survey Territories, Miscelaneous Publications 12:1-190.

BıGG, M. A. 1988. Status of the California sea lion, Zalophus californianus, in Canada. Canadian Field Naturalist 102:307-314.

Ceballos, G., S. Pompa, E. Espinoza, and A. García. 2010. Extralimital Distribution of Galapagos (Zalophus wollebaeki) and Northern (Eumetopias jubatus) Sea Lions in Mexico. Aquatic Mammals 36:188-194.

El Imparcial, Hermosillo. 2004. Rescatan a lobo marino. Sección Nacional. 16/A. Lunes 26 de Abril de 2004. Available at jpgallo@ciad.mx

Elorriaga-Verplancken, F. R., and M. T. Brown. 2014. Unprecedented resighting in Mexico of a Male California Sea Lion (Zalophus californianus) from Oregon During the 2014 Breeding Season. Aquatic Mammals 40:364-367.

Gallo-Reynoso, J. P., and A. Ortega. 1986. The first report of Zalophus californianus, in Acapulco, México. Marine Mammal Science 2:158.

Gallo-Reynoso, J. P., and J. L. Solórzano. 1991. Two new sightings of California sea lions on the southern coast of Mexico. Marine Mammal Science 7:96.

KING, J. E. 1983. Seals of the world. Cornell University Press. Ithaca, New York.

Le Boeuf, B. J., D. Aurioles-Gamboa, R. Condit, C. Fox, R. Gisiner, R., Romero, and F. Sinsel. 1983. Size and distribution of the California sea lion population in México. Proceedings of the California Academy of Sciences 43:77-85.

Lowry, M. S. 1985. Movements of California sea lions (Zalophus californianus) from tag resights. Pages 167172 in Mem. X Reunión Internacional sobre los Mamíferos Marinos. La Paz, México. March 1985.

Maniscalco, J., K. Wynne, K. Pitcher, M. Hanson, S. Melin, and S. Atkinson. 2004. The occurrence of California sea lions (Zalophus californianus) in Alaska. Aquatic Mammals 30:427-433.

Meraz, J., And V. M. Sánchez-Díaz. 2008. Los mamíferos marinos en la Costa Central de Oaxaca. Marine mammals along the central coast of Oaxaca. Revista Mexicana de Biodiversidad 79:143.151.

Ortega-Ortiz, C. D., F. Elorriaga-Verplancken, L. Rodríguez-Téllez, A. Olivos-Ortiz, and J. H. Gaviño-Rodríguez. 2013. Primer registro de un lobo marino de California (Zalophus californianus) neonato en Manzanillo, Colima, México. Revista Mexicana de Biodiversidad 84:705-708. 
Pérez-Cossío I. J. 2015. Hábitos alimentarios del lobo marino de California (Zalophus californianus) en la Isla Farallón de San Ignacio, Sinaloa, México. Bachelor's Thesis, Universidad Autónoma de Sinaloa, Escuela de Biología. Available at jpgallo@ciad.mx

Repenning, C. A., R. S. Peterson, and C. L. Hubbs. 1971. Contribution to the systematics of the southern fur seals, with particular reference to the Juan Fernandez and Guadalupe species. Pp.18-34 in Antarctic pinnipeds (Burt, W. H. ed.). American Geophysical Union. Washington. EE. UU.

Richards, A. F. 1964. Geology of the Islas Revillagigedo, Mexico 4. Geology and petrography of Isla Roca Partida. Geological Society of America Bulletin 75:1157-1164.

RTG (Radio y Televisión de Guerrero) Noticias. 2012. Rescate de lobo marino en Acapulco. http://rtvgro. net/nt/blog/2012/06/13/rescate-de-lobo-marino-en-acapulco/ (2 de 6)23/06/2012 10:57:28 p.m. Available at jpgallo@ciad.mx

Trillmich, F. And T. Dellinger. 1991. The effect of El Niño in Galapagos Pinnipeds. Pp. 66-74 in Pinnipeds and El Niño. Responses to environmental stress (Trillmich, F., and K. Ono, eds.). Springer-Verlag. Berlin, Germany.

Young, J., C. J. Hernández-Camacho, and L. R. Gerber. 2007. Long-distance movement of a pinniped neonate. Marine Mammal Science 23:926-930.

Weise, M. J., D. P. Costa, And R. M. Kudela. 2006. Movement and diving behavior of male California sea lion (Zalophus californianus) during anomalous oceanographic conditions of 2005 compared to those of 2004. Geophysical Research Letters 33:L22S10.

Summited: March 10, 2015

Review: May 8, 2015

Accepted: May 9, 2015

Associated editor: Cristina Macswiney 